\title{
Poverty Reduction Through Microfinance in Rajapolah District, Tasikmalaya Regency
}

\author{
Wilman San Marino*, Gun Gun Gunawan \\ Finance and Banking \\ Politeknik Triguna Tasikmalaya \\ Tasikmalaya, Indonesia \\ *wilmansanmarino@gmail.com,gg.silung.gunawan@gmail.com
}

\begin{abstract}
The rapid growth of microfinance institutions provides great opportunities for low-income people to participate more in the economy, start and grow their businesses. This study aims to determine the role of microfinance institutions in reducing poverty with indicators of increasing family income before and after receiving microfinance for women. The research method used in this research is quantitative research methods and explanatory surveys. Model testing using paired $t$ test. The population in this study were women receiving microfinance in Rajapolah Village, Rajapolah District, Tasikmalaya Regency. The sampling technique used simple random sampling and was determined by the slovin formula obtained 150 people. Based on the results of the study showed that there were significant differences in family income after receiving microfinance financing. Financial institutions play a role in increasing the family income of women receiving microfinance. Microfinance for women is an effective way to increase family income as an effort to reduce poverty.
\end{abstract}

\section{Keywords-microfinance, poverty reduction}

\section{INTRODUCTION}

Poverty reduction is one component of the Sustainable Development Goals (SDGs) which is a commitment from the Indonesian government and the countries that are members of the United Nations in ensuring that all human beings can enjoy peace and prosperity by 2030 . Commitment In achieving the SDGs, Indonesia is not merely fulfilling global agreements but is an effort to achieve Indonesia's aspirations in improving the welfare of its people. SDGs is a common goal that requires real contributions from the government and various components of society [1].

The composition of the poor in Indonesia in 2015 was $11.22 \%$ of the total population of Indonesia. At the beginning of 2019 , there were $9.64 \%$ poor people and it is hoped that the intervention from the government will be at $9.49 \%$ in accordance with the government's target of $8.5 \%-9.5 \%$. The Indonesian government predicts that the composition of the poor in early 2030 will be $5.73 \%$ who will be intervened with various policies so that it is expected that by the end of 2030 it will be $4.33 \%$ according to the government's target of $4-4.5 \%$.
[1]. Based on data from the first quarter of 2019 , the poverty line in Indonesia is IDR 425,250 / month, with this amount the poor population in Indonesia is around 25 million people with a proportion about 9.40 percent. One of the characteristics of poverty in Indonesia can be seen from the disparity between rural areas where the poverty rate is almost twice that of urban areas [2].

Achieving poverty alleviation requires collaboration between stakeholders, division of roles, and innovative strategies. One of the stakeholders that is expected to play a major role in poverty reduction is financial institutions, starting large scale through banking, cooperatives and even to the smallest scale, namely microfinance institutions. The purpose of establishing a bank is to improve the standard of living of the people at large. Likewise, cooperatives have the same goals, where one of the functions of the cooperative is to build and develop the potential and economic capacity of members in particular and society in general as well as to participate in building the national economic order in the context of realizing an advanced, just and prosperous society.

Without prejudice to the role of large and medium scale financial institutions, there is evidence that the role of microfinance institutions is an effective tool in poverty alleviation and socio-economic development [3-7]. The Microcredit Summit Campaign in 2010 reported that 3,652 microfinance institutions had a total customer base of 205 million, 137 million of whom were among the poorest when taking their first loan with a portion of $82.3 \%$ being female customers [8].

The development of microfinance institutions, both in terms of the number of institutions and the number of customers in Indonesia, is quite rapid, one of which occurs in Rajapolah Village, Rajapolah District. The purpose of this study was to determine the magnitude of the influence of microfinance service on poverty reduction in the Rajapolah District, Tasikmalaya Regency.

The beginnings of microfinance can be found in various regions, but the most famous story was popularized in Bangladesh by Nobel Peace Prize winner Prof. Muhammad 
Yunus more than 30 years ago with the aim of reducing poverty by making small loans to the country's rural poor [9].

Micro-credit extension institutions have developed over the years and not only provide credit to the poor, but now also cover a range of other services including savings, insurance (micro insurance), remittances and non-financial services such as financial literacy training and skills development programs, even in several places (for example: BRAC in Bangladesh which is one of the pioneers), it has also assisted customers in distributing and marketing their products, making micro credit channelling institutions transformed into microfinance institutions $[6,10]$.

A key feature of microfinance institutions is targeting women on the grounds that, compared to men, women perform better as clients and their participation shows more desirable development outcomes [11]. Microfinance institutions affect households more than just an economic outcome in the form of increased income, but provide social benefits and empowerment for women $[4,6,12,13]$.

SDGs aim to end poverty in all forms and wherever it exists. Although previously defined only in monetary terms, poverty is now understood to include the realities of life from people's experiences and the various deprivations they face. Since 2010, the global Multidimensional Poverty Index (MPI) has compared acute multidimensional poverty in more than 100 countries. The Global MPI examines individual deprivation across 10 indicators in three equally demanding dimensions covering health, education and living standards by offering a detailed perspective on identifying who is poor and how they are poor [14].

A comprehensive understanding of poverty is needed to determine the right coping strategy. There are several problems related to the powerlessness of the community in facing poverty, namely 1). The empirical experience regarding the failure to reduce poverty in an effective and sustainable manner, this is because poverty is becoming more complex, not just meeting basic needs. 2). Solving the problem of poverty does not only lie in economic problems, but also develops into political, social and even cultural problems [15].

The characteristics of poor households in Indonesia can be seen from several aspects including demography, education, employment and housing [2]. The poverty line in Indonesia as of the first quarter of 2019 is IDR 425,250 /cap /month. For example, if a household with 4 family members has an income of less than IDR 1,701,000, it is categorized as a poor family.

\section{METHODS}

The research method used is descriptive quantitative and explanatory survey to describe the profile, characteristics, relevant aspects related to humans, organizations / industries so that actual and important findings about the phenomena that occur in poverty alleviation efforts in Rajapolah District, Tasikmalaya Regency, and understand / analyse the relationship with the aim of answering questions related to the facts obtained on the variables studied $[16,17]$.

The test used Paired Sample t-test to see differences in family income before and after receiving microfinance services. The data used in this study are primary data, with survey data collection techniques. The population of this research is female microfinance customers in Rajapolah Village, Rajapolah District, Tasikmalaya Regency, West Java, with a total of 225 people. The sample technique uses Simple Random Sampling and determined using the Slovin formula with an alpha level of $5 \%$, then the total sample size is 150 .

\section{RESULTS AND DISCUSSION}

\section{A. Results}

Characteristics of respondents based on the results of data processing (Table 1).

TABLE I. CHARACTERISTICS OF RESPONDENTS

\begin{tabular}{|l|l|l|l|}
\hline Category & \multicolumn{1}{|c|}{ Description } & Amount & Percent (\%) \\
\hline \multirow{4}{*}{ Age } & $25-35$ years & 21 & 14 \\
\cline { 2 - 4 } & $36-45$ years & 58 & 39 \\
\cline { 2 - 4 } & $46-55$ years & 51 & 34 \\
\cline { 2 - 4 } & $>55$ years & 20 & 13 \\
\hline \multirow{3}{*}{$\begin{array}{l}\text { Level of } \\
\text { education }\end{array}$} & primary school & 106 & 71 \\
\cline { 2 - 4 } & Junior high school & 32 & 21 \\
\cline { 2 - 4 } & Senior High School & 12 & 8 \\
\hline
\end{tabular}

Respondents consisted of women with the majority aged between 36 - 45 years as much as $39 \%$, followed by the age of respondents between 46 - 55 years at $34 \%$ and the remaining $27 \%$ consisting of the age range of $25-35$ years and over 55 years. The majority of respondents' education level is $71 \%$ through elementary school and the rest $29 \%$ has a high school level.

TABLE II. ONE-SAMPLE KOLMOGOROV-SMIRNOV TEST

\begin{tabular}{|c|l|l|}
\hline & before financing & after financing \\
\hline Kolmogorov-Smirnov $\boldsymbol{Z}$ & .782 & 1.273 \\
\hline Asymp. Sig. (2-tailed) & .573 & .078 \\
\hline
\end{tabular}

Test distribution is Normal.

Source: Data processing results, 2020

Based on the test results table 2, it shows that family income before and after getting financing has an Asymp. Sig value more than 0.05 , which means that both data are normally distributed.

TABLE III. PAIRED SAMPLES STATISTICS

\begin{tabular}{|l|l|l|}
\hline \multicolumn{2}{|c|}{} & \multicolumn{1}{|c|}{ Mean } \\
\hline \multirow{2}{*}{ Pair 1 } & Before Financing & 2.31731 \\
\cline { 2 - 3 } & After Financing & 2.84395 \\
\hline
\end{tabular}

Source: Data processing results, 2020. 
Table 3 shows that the average income shows positive results with an increasing trend of 0.52664 after getting financing.
TABLE IV. PAIRED SAMPLES CORRELATIONS

\begin{tabular}{|l|ll|c|l|c|}
\hline & & N & Correlation & Sig. \\
\hline Pair 1 & $\begin{array}{l}\text { Before- } \\
\text { Financing }\end{array}$ & After & 150 & 0.758 & 0.000 \\
\hline
\end{tabular}

The correlation value in table 4 is 0.758 , indicating a strong relationship between variables.

TABLE V. PAIRED SAMPLES TEST

\begin{tabular}{|c|c|c|c|c|c|c|c|c|c|c|}
\hline & & & \multicolumn{5}{|c|}{ Paired Differences } & \multirow{3}{*}{$\mathbf{t}$} & \multirow{3}{*}{ df } & \multirow{3}{*}{$\begin{array}{l}\text { Sig. (2- } \\
\text { tailed) }\end{array}$} \\
\hline & & & \multirow[t]{2}{*}{ Mean } & \multirow[t]{2}{*}{$\begin{array}{c}\text { Std. } \\
\text { Deviation }\end{array}$} & \multirow[t]{2}{*}{$\begin{array}{l}\text { Std. } \\
\text { Error } \\
\text { Mean }\end{array}$} & \multicolumn{2}{|c|}{$\begin{array}{l}\text { 95\% Confidence } \\
\text { Interval of the } \\
\text { Difference }\end{array}$} & & & \\
\hline & & & & & & Lower & Upper & & & \\
\hline Pair 1 & $\begin{array}{l}\text { Before } \\
\text { After } \\
\text { Financing }\end{array}$ & & -0.5266 & 0.628 & 0.0513 & -0.627914 & -0.42537 & -10.28 & 149 & .000 \\
\hline
\end{tabular}

Based on table 5, it is found that the significance of 0.000 is less than the significant level of 0.05 , indicating that there is a significant difference between the average value before and after getting financing. The negative $t$ value is $-10,276$, it can be concluded that there is an increase in family income after receiving financing.

\section{B. Discussion}

Based on the research results, it is known that Microfinance have a significant influence on poverty reduction, this means that the higher the quality of Microfinance services, the more it plays a role in poverty a reduction.

Financing makes women empowered is very closely related to poverty reduction. Associated with the neoclassical assumptions regarding the production function, if women have less access to capital than men, then the return on capital for women should be higher than for men. Thus, giving women more capital in principle can increase economic growth, increase income and end up reducing the level of household poverty [6].

The rapid growth of microfinance institutions is beneficial for the economy. The logic is that when the services of microfinance institutions have wide and quality services, people with low incomes have the opportunity to participate in the economy, start new businesses, and even develop their businesses. As a result, there was an increase in income, the community was able to meet their household needs independently and sustainably. Research on the influence of microfinance on poverty reduction has been carried out in various regions. In Bangladesh, which is known as the pioneer of MFIs, there are many studies that confirm how MFIs influence poverty alleviation $[6,18]$.

In Malaysia microfinance Amanah Ikhtiar Malaysia (AIM) plays an important role in the socio-economic development of poor and low-income communities, especially women $[19,20]$.
In Indonesia, a study on the impact of microfinance PNM Mandiri on poverty reduction by $20 \%$ [21].

\section{CONCLUSION}

Microfinance have a significant effect on poverty reduction. Microfinance institution not only play a role in distributing microfinance, they also play a role in mentoring, increasing the knowledge and skills of their customers through training and workshops so that customers can manage the financing they receive more productively so that household income can be increased higher.

Further research to see the effect of Microfinance on poverty reduction is suggested to use a larger number of objects with a more diverse research area, besides that the poverty measurement figures can be more comprehensive using the Multidimensional Poverty Index.

\section{REFERENCES}

[1] Kementerian Perencanaan Pembangunan Nasional, "Peta Jalan SDGs Indonesia," Jakarta, 2019.

[2] Badan Pusat Statistik, "Penghitungan dan Analisis Kemiskinan Makro Indonesia Tahun 2019," Penghitungan dan Anal. Kemiskin. Makro Indones. Tahun 2019, no. 1, p. xvi+72, 2019.

[3] S. Samer, I. Majid, S. Rizal, M.R. Muhamad, Sarah-Halim, and N. Rashid, "The Impact of Microfinance on Poverty Reduction: Empirical Evidence from Malaysian Perspective," Procedia - Soc. Behav. Sci., vol. 195, pp. 721-728, 2015.

[4] M. Duvendack, R. Palmer-Jones, J.G. Copestake, L. Hooper, Y. Loke, and N. Rao, What is the evidence of the impact of microfinance on the well-being of poor people? Systematic review, no. August. London: EPPI-Centre: ocial Science Research Unit, Institute of Education, University of London, 2011.

[5] S.R. Khandker and G.B. Koolwal, "How has microcredit supported agriculture? Evidence using panel data from Bangladesh," Agric. Econ. (United Kingdom), vol. 47, no. 2, pp. 157-168, 2016. 
[6] B.A. de Aghion and J. Morduch, The Economics of Microfinance, 2nd ed. Cambridge, Massachusetts: The MIT Press, 2010.

[7] S.A. Fagen, N.J. Long, and D.J. Stevens, Teaching children self-control: Preventing emotional and learning problems in the elementary school. Columbus, OH: Charles E. Merrill, 1975.

[8] J.P. Maes and L.R. Reed, State of the Microcredit Summit Campaign Report 2012. Washington, DC: the Microcredit Summit Campaign (MCS), 2012.

[9] M. Yunus, "Grameen Bank," Scientific American, no. November, Nov1999.

[10] M. Robinson, The Microfinance Revolution: Sustainable Banking for the Poor. Washington, DC: The World Bank, 2001.

[11] M.M. Pitt and S.R. Khandker, "The impact of group-based credit programs on poor households in Bangladesh: Does the gender of participants matter?,” J. Polit. Econ., vol. 106, no. 5, pp. 958-996, 1998.

[12] D. Karlan, "Expanding Credit Access: Using Randomized," Rev. Financ. Stud., vol. 23, no. 1, pp. 433-464, 2009.

[13] A. Banerjee, E. Duflo, R. Glennerster, and C. Kinnan, "The miracle of microfinance? Evidence from a randomized evaluation," Am. Econ. J. Appl. Econ., vol. 7, no. 1, pp. 22-53, 2014.

[14] UNDP and OPHI, "Charting pathways out of multidimensional poverty: Achieving the SDGs," 2020.
[15] A. Sen, "The Standard of Living," in Clare Hall, Cambridge University, 1987.

[16] U. Sekaran and R. Bougie, Research Methods for Business, 7th ed. Chichester, West Sussex, United Kingdom: John Wiley \& Sons Ltd. 2016.

[17] E. Babbie, The Practice of Social Research. Boston, MA: Cengage Learning, 2016.

[18] S.R. Khandker, "Microfinance and Poverty : Evidence Using Panel Data from Bangladesh,” World Bank Econ. Rev., vol. 19, no. 2, pp. 263-286, 2005.

[19] A. Al-Mamun, M.N.H. Mazumder, and C.A. Malarvizhi, "Measuring the effect of Amanah Ikhtiar Malaysia's microcredit programme on economic vulnerability among hardcore poor households," Prog. Dev. Stud., vol. 14, no. 1, pp. 49-59, 2014.

[20] S.S.A. Al-shami, M.M. Razali, I. Majid, A. Rozelan, and N. Rashid, "The effect of microfinance on women's empowerment: Evidence from Malaysia," Asian J. Women's Stud., vol. 22, no. 3, pp. 318-337, 2016.

[21] A. Nihayah, "Pengaruh Program Simpan Pinjam Kelompok Perempuan Terhadap Pendapatan Usaha Mikro Kecil dan Poverty Reduction Dalam Perspektif Ekonomi Islam (Studi Kasus PNPM Mandiri Perdesaan Kecamatan Bangilan, Tuban).," Econ. J. Ekon. dan Huk. Islam, vol. 5, no. 2, pp. 1-24, 2015 . 